\title{
Comparative Assessment of Physicochemical and Biological Quality Characters of Vermicompost from Different Biomass Substrates
}

\author{
Ajeet Kumar*, Sankar Ch. Paul, Amarjeet Kumar and Mukta Rani \\ Department of Soil Science and Agricultural Chemistry, Bihar Agricultural College, \\ Sabour, Bhagalpur, Bihar-813210, India \\ *Corresponding author
}

\section{A B S T R A C T}

\section{Keywords}

Physicochemical and biological characters,

Vermicompost, Biomass substrate, Water hyacinth, coconut leaf

Article Info

Accepted:

04 December 2017

Available Online:

10 January 2018
In vermicomposting, variation in particle size, palatability and metabolites of solid organic wastes may influence the performance of earthworm as well as quality of its final product. Therefore, the study was taken to characterize the vermicomposts prepared from two different sources i.e. water hyacinth and coconut leaf respectively. Vermicompost of water hyacinth and coconut leaf showed almost similar $\mathrm{pH}$ and EC values by Jackson method (1973) but these showed higher in FCO method (1985). CEC value for both vermicompost was 74.20 and $72.60 \mathrm{cmol}(+) \mathrm{kg}^{-1}$. The Organic carbon content $(23.1 \%)$ was recorded in water hyacinth vermicompost while as coconut leaf vermicompost $(22.5 \%)$. Water holding capacity was much higher (213.90 and 226.2\%) as compare to cultivated soil. Available form of $\mathrm{N}, \mathrm{P}, \mathrm{K}, \mathrm{S}, \mathrm{Zn}, \mathrm{Cu}, \mathrm{Mn}$ and $\mathrm{Fe}$ was found in less content with respect to total $\mathrm{K}$ and $\mathrm{Na}$ content in both types of vermicompost. Available part of the nutrients was more pronounced in water hyacinth vermicompost than coconut leaf vermicompost while as microbial population was accounted higher in water hyacinth vermicompost than coconut leaf vermicompost respectively. Water hyacinth vermicompost contains higher values of dehydrogenase activity, microbial biomass carbon content as well as urease enzyme activity. Results represented that water hyacinth vermicompost is better in quality than coconut leaf vermicompost with respect to its microbial properties.

\section{Introduction}

In an estimate, the annual total crop residues generated by the world population is projected around 3.8 billion tonnes (Lal, 2005). Around 3 thousand million tonnes of wastes annually produced in India, out of which more than $60 \%$ are decomposable (Chauhan et al., 2010). These large quantities of plant residues may serve as potential sources of plant nutrients (Suthar, 2007). These wastes may be recycled by making manure, compost as well as vermicompost which are the best options for its management (Bhat et al., 2013). Animal wastes also require a route for recycling into valuable end product rather being desecrate and discharge in the environment. Composting by using earthworm which offers the rapid recovery of valuable resources from biodegradable plant and animal wastes to humus-like vermicompost at a very short period of time (Pramanik et al., 2007). A large 
area of Southern and eastern India which occupy coconut and a recanut plantation that supplies the huge quantities of coconut leaf biomass per year. Generally, these are burnt in the field and causing pollution to the environment. Large quantity of water hyacinth grows naturally in India under low land areas and stagnant water bodies. Water hyacinth is an aquatic weed which causes economic as well as environmental losses in many countries due to its rapid growth habits. It can obstruct the access to the pumps used for irrigation, causing water resources depletion, and the spreading of mosquitoes and flies which are vectors of a number of diseases (Ding et al., 2001). There are several ways to control water hyacinth like mechanical, biological, and chemical methods. However, it is also used to produce valuable products such as, biogas, compost and vermicompost (Malik, 2007). To turning of these plant residues and animal excreta into a valuable end product i.e. vermicompost will be an option to manage these waste products profitably. However, the organic wastes have different palatability, particle size, metabolites etc. that may influence the growth and performances of earthworms (Suthar, 2007). The substrate and manner of composting dictates the essential properties of the compost like, $\mathrm{C} / \mathrm{N}$ ratio, available macronutrients (e.g., N, P, K, S) and micronutrients (e.g., Fe, Cu, Zn, Mn, B) for plant and associated micro-flora and fauna (bacteria and fungi). These factors affect the quality of vermicompost. By keeping of this view to understand the variation in quality of vermicompost from different substrates, the study was conducted to evaluate the vermicompost produced from locally grown water hyacinth and coconut leaf biomass respectively.

\section{Materials and Methods}

The present study was undertaken to characterise the two types of vermicompost i.e., vermicompost of water hyacinth and of coconut leaf biomass along with a soil sample collected from BAU farm, Sabour. $\mathrm{pH}$ and EC were measured by the method described by Jackson (1973) and FCO (1985). Cation exchange capacity was determined by neutral normal ammonium acetate $\left(1 \mathrm{~N} \mathrm{NH}_{4} \mathrm{OAc}\right)$ with the help of the method of Schollenberger as described in Black (1965). Organic carbon was determined by wet digestion method of Walkley and Black (1934) as described in Black (1965). Available nitrogen was estimated by alkaline permanganate oxidation method as described by Subbaiah and Asija (1956). Exchangeable $\mathrm{NH}_{4}{ }^{+}$and $\mathrm{NO}_{3}^{-}$nitrogen present in vermicomposts and soil were determined by the method of Kenny and Bremner (1962) as described by Page et al., (1982).Available phosphorus content was estimated by Olsen's method (Olsen et al., 1954). Available potassium and sodium in soil and vermicompost were determined by neutral ammonium acetate $(1 N)$ extract using flame photometer (Jackson, 1973). Extraction of available sulphur was done by using $0.15 \%$ $\mathrm{CaCl}_{2}$ as per the method of Williams and Steinbergs (1959) and the extracted sulphur was estimated by turbidimetrically method of Chesnin and Yien (1951) using a spectrophotometer at $420 \mathrm{~nm}$ wavelength. Available $\mathrm{Fe}, \mathrm{Cu}, \mathrm{Zn}, \mathrm{Mn}$ were estimated by Lindsay and Norvell (1978) method with the help of atomic absorption spectrophotometer.

Total nitrogen present in vermicompost and soil was determined by standard method (Piper, 1966). Total phosphorous of vermicompost and soil was determined by diacid digestion and phosphorus in the digest was estimated by the vanadomolybdate yellow colour method (Page et al., 1982). Total potassium and sodium were determined by using known volume of digest (prepared as in total phosphorus) and estimated by flame photometer (Page et al., 1982). Total sulphur in the digest was estimated by using $\mathrm{BaCl}_{2}$ 
crystal (Tabatabai et al., 1982) with the help of spectrophotometer $(420 \mathrm{~nm})$. Total $\mathrm{Fe}, \mathrm{Cu}$, $\mathrm{Zn}$, Mn were determined by using known volume of digest (prepared as in total phosphorus) with the help of AAS (Atomic absorption spectrophotometer).

Microbial population like total bacteria, total actinomycetes, total fungi, azotobacter, and phosphorus solubilising bacteria (PSB) were also taken into account by counting colony forming unit ( $\mathrm{cfu} \mathrm{g}^{-1}$ ) through serial dilution plate technique (Allen, 1960). Microbial biomass carbon was estimated in chloroform fumigation extraction procedure as described by Jenkinson and Powlson (1976) and calculation was made by Vance et al., (1987). Dehydrogenase activity in soil and vermicompost was determined by the spectrophotometer (Klein et al., 1971). Urease enzyme activity in samples was estimated by Tabatabai and Bremner (1972).

\section{Results and Discussion}

\section{Physico-chemical vermicomposts \\ properties}

of

Results of physicochemical properties of two different types of vermicompost along with a cultivated soil which are presented in Table 1. Both type of vermicompost showed similar $\mathrm{pH}$ values i.e. 6.81 (water hyacinth) and 6.92 (coconut leaf) respectively i.e., less than cultivated soil (7.94). $\mathrm{pH}$ value determined by FCO method (1985) showed little higher than normal $\mathrm{pH}$ method $(1: 2.5)$ by Jackson but the magnitude was higher in coconut leaf vermicompost $(0.31)$ than water hyacinth vermicompost $(0.22)$ that may be explained by higher quantities of $\mathrm{Na}, \mathrm{K}$ content in it which neutralise carboxylic group and other acids after long time shaking ( 2 hour). Electrical conductivity (EC) value showed similar trend. Highest EC value observed in water hyacinth vermicomost $\left(3.35 \mathrm{dS} \mathrm{m}^{-1}\right)$ in FCO method
(1985) whereas coconut leaf vermicompost resulting $2.25 \mathrm{dS} \mathrm{m}^{-1}$ which is showed in Figure 1 that indicates the presence of little quantities of soluble salts in the vermicompost casts and soluble salt content is more in water hyacinth vermicompost than coconut leaf vermicompost respectively. Irshad et al., (2013) reported that higher EC values in composted manures could be attributed to the release of salts from the manure with the passage of time. Cation exchange capacity of both types vermicompost was about to similar [74.20 and $\left.72.60 \mathrm{cmol}(+) \mathrm{kg}^{-1}\right]$. Organic carbon content in water hyacinth vermicompost was $23.1 \%$ and in coconut leaf vermicompost $22.5 \%$. Maximum water holding capacity was much higher (213.90 and $226.20 \%)$ than cultivated soil $(41.00 \%)$.

Available nitrogen in water hyacinth and coconut leaf vermicompost were $443.40 \mathrm{mg}$ $\mathrm{kg}^{-1}$ and $417.20 \mathrm{mg} \mathrm{kg}^{-1}$ (Fig. 2) which contributed to $3.26 \%$ and $2.87 \%$ of total nitrogen content $(1.36 \%$ and $1.45 \%)$, respectively. Ammonium form of nitrogen content was higher than the nitrate formin both the vermicompost and cultivated soil. Available phosphorus content in water hyacinth and coconut leaf vermicompost were $52.30 \mathrm{mg} \mathrm{kg}^{-1}$ and $36.32 \mathrm{mg} \mathrm{kg}$ which explained $0.83 \%$ and $0.69 \%$ of total $\mathrm{P}(0.63$ and $0.52 \%$ ) content, respectively. Comparatively much higher content of available $\mathrm{K}$ found in both vermicompost (1882.33 $\mathrm{mg} \mathrm{kg}^{-1}$ and $2047.00 \mathrm{mg} \mathrm{kg}^{-1}$ ) which was 36.47 and $36.55 \%$ of total content of $\mathrm{K}$. Similar trend was found in analysis of $\mathrm{Na}$ content. Available sulphur content in water hyacinth as well as coconut leaf vermicompost were 118.62 and $93.43 \mathrm{mg} \mathrm{kg}{ }^{-1}$ which contributed 4.28 and $4.04 \%$ of total $\mathrm{S}$ content respectively. Higher content of total $\mathrm{N}$ and $\mathrm{K}$ was found in coconut leaf vermicompost (Fig. 3) than water hyacinth vermicompost but reverse found for total $\mathrm{P}, \mathrm{Na}$ and $\mathrm{S}$. Micronutrient contents were much less than 
the macronutrient content. Available micronutrient content in water hyacinth as well as coconut leaf vermicompost resulted 1.16 and $1.04 \mathrm{mg} \mathrm{kg}^{-1}$ for $\mathrm{Cu}$ which resulted 0.99 and $1.08 \%$ of total content, 4.84 and 6.74 $\mathrm{mg} \mathrm{kg}{ }^{-1}$ for $\mathrm{Zn}$ that contributed 9.68 and $8.98 \%$ of total $\mathrm{Zn}$ content, 21.22 and $17.02 \mathrm{mg}$ $\mathrm{kg}^{-1}$ for $\mathrm{Fe}$ which was 0.67 and $0.84 \%$ of total content and 14.42 and $16.72 \mathrm{mg} \mathrm{kg}^{-1}$ for $\mathrm{Mn}$ which explained 6.08 and $4.77 \%$ of total $\mathrm{Mn}$. It has been understood from these results that, available part of nutrients were more pronounced in water hyacinth vermicompost than coconut leaf vermicompost that may be due to higher lignin and cellulose content in coconut leaf that produce more complex humus and make metal humus complex.

The coconut leaf vermicompost content higher amount of total $\mathrm{Zn}$ and $\mathrm{Mn}$ but lower amount of total $\mathrm{Cu}$ in comparison to water hyacinth vermicompost shown in Figure 4.

Table.1 Physicochemical characteristics of vermicompost among two different substrates (water hyacinth and coconut leaf) and cultivated soil

\begin{tabular}{|c|c|c|c|}
\hline Characteristics & $\begin{array}{l}\text { Vermicompost } \\
\text { (water hyacinth) }\end{array}$ & $\begin{array}{l}\text { Vermicompost } \\
\text { (coconut leaf) }\end{array}$ & $\begin{array}{c}\text { Cultivated } \\
\text { soil }\end{array}$ \\
\hline $\mathrm{pH}(1: 2.5)$ & 6.81 & 6.92 & 7.94 \\
\hline $\mathrm{pH}(\mathrm{FCO}, 1985)$ & 7.03 & 7.23 & - \\
\hline $\mathrm{EC}(1: 2.5)\left(\mathrm{dS} \mathrm{m}^{-1}\right)$ & 2.00 & 1.80 & 0.20 \\
\hline $\mathrm{EC}(\mathrm{FCO}, 1985)\left(\mathrm{dS} \mathrm{m}^{-1}\right)$ & 3.35 & 2.25 & - \\
\hline CEC $\left[\mathrm{cmol}(+) \mathrm{kg}^{-1}\right]$ & 74.20 & 72.60 & 8.60 \\
\hline Organic carbon (\%) & 23.10 & 22.50 & 0.67 \\
\hline Max. Water Holding Capacity (\%) & 213.90 & 226.20 & 41.00 \\
\hline \multicolumn{4}{|c|}{ Available macro and micro nutrients } \\
\hline Available $\mathbf{N}\left(\mathrm{mg} \mathrm{kg}^{-1}\right)$ & $443.40(3.26 \%)^{*}$ & $417.20(2.87 \%)$ & $98.28(13.5 \%)$ \\
\hline $\mathrm{NH}_{4}{ }^{+}-\mathrm{N}\left(\mathrm{mg} \mathrm{kg}^{-1}\right)$ & $219.30(1.61 \%)$ & $204.40(0.98 \%)$ & $18.16(2.48 \%)$ \\
\hline $\mathrm{NO}_{3}{ }^{-}-\mathrm{N}\left(\mathrm{mg} \mathrm{kg}^{-1}\right)$ & $157.60(1.15 \%)$ & $142.80(0.98 \%)$ & $7.60(1.04 \%)$ \\
\hline Available P $\left(\mathrm{mg} \mathrm{kg}^{-1}\right)$ & $52.30(0.83 \%)$ & $36.32(0.69 \%)$ & $11.42(0.51 \%)$ \\
\hline Available K (mg kg $\left.{ }^{-1}\right)$ & $1882.33(36.47 \%)$ & $2047.00(36.55 \%)$ & $97.20(3.70 \%)$ \\
\hline Available $\mathrm{Na}\left(\mathrm{mg} \mathrm{kg}^{-1}\right)$ & $406.00(33.27 \%)$ & $489.7544 .52 \%)$ & $164.90(4.02 \%)$ \\
\hline Available S $\left(\mathrm{mg} \mathrm{kg}^{-1}\right)$ & $118.62(4.28 \%)$ & $93.43(4.04 \%)$ & $18.40(1.18 \%)$ \\
\hline Available $\mathrm{Cu}\left(\mathrm{mg} \mathrm{kg}^{-1}\right)$ & $1.16(0.99 \%)$ & $1.04(1.08 \%)$ & $1.37(9.78 \%)$ \\
\hline Available $\mathrm{Zn}\left(\mathrm{mg} \mathrm{kg}^{-1}\right)$ & $4.84(9.68 \%)$ & $6.74(8.98 \%)$ & $1.02(4.43 \%)$ \\
\hline Available Fe $\left(\mathrm{mg} \mathrm{kg}^{-1}\right)$ & $21.22(0.67 \%)$ & $17.02(0.84 \%)$ & $39.47(0.63 \%)$ \\
\hline Available Mn ( $\left.\mathrm{mg} \mathrm{kg}^{-1}\right)$ & $14.42(6.08 \%)$ & $16.72(4.77 \%)$ & $20.20(6.43 \%)$ \\
\hline \multicolumn{4}{|c|}{ Total content of macro and micro nutrients } \\
\hline Total N (\%) & 1.36 & 1.45 & 0.073 \\
\hline Total P (\%) & 0.63 & 0.52 & 0.22 \\
\hline Total K (\%) & 0.52 & 0.56 & 0.26 \\
\hline Total Na $(\%)$ & 0.12 & 0.11 & 0.41 \\
\hline Total S (\%) & 0.27 & 0.23 & 0.15 \\
\hline Total Cu (\%) & 0.0117 & 0.0096 & 0.0014 \\
\hline Total Zn (\%) & 0.0050 & 0.0075 & 0.0023 \\
\hline Total Fe (\%) & 0.3167 & 0.2022 & 0.6246 \\
\hline Total Mn (\%) & 0.0237 & 0.0350 & 0.0314 \\
\hline
\end{tabular}

* Value in the parenthesis indicates percent of total content. 
Table.2 Biological characteristics of vermicompost of two different substrate (water hyacinth and coconut leaf) and cultivated soil

\begin{tabular}{|c|c|c|c|}
\hline Characteristics & $\begin{array}{l}\text { Vermicompost } \\
\text { (water hyacinth) }\end{array}$ & $\begin{array}{l}\text { Vermicompost } \\
\text { (coconut leaf) }\end{array}$ & $\begin{array}{l}\text { Cultivated } \\
\text { Soil }\end{array}$ \\
\hline Bacteria (x 10 ${ }^{6} \mathrm{CFU} \mathrm{g}^{-1}$ dry soil) & 71.70 & 47.40 & 32.60 \\
\hline Fungi (x 10 ${ }^{4} \mathrm{CFU} \mathrm{g}^{-1}$ dry soil) & 23.60 & 17.40 & 12.40 \\
\hline Actinomycetes $\left(\mathrm{x} 10^{6} \mathrm{CFU} \mathrm{g}^{-1}\right.$ dry soil) & 15.40 & 15.00 & 8.40 \\
\hline Azotobacter(x 10 CFU g $^{-1}$ dry soil) & 12.30 & 8.40 & 6.30 \\
\hline $\operatorname{PSB}\left(x 10^{6} \mathrm{CFU} \mathrm{g}^{-1}\right.$ dry soil) & 13.60 & 7.30 & 4.00 \\
\hline $\begin{array}{l}\text { Dehydrogenase Activity } \\
\left(\mu \mathrm{g} \mathrm{TPF}^{-1} \mathrm{~g}^{-1} \text { dry soil) }\right.\end{array}$ & 87.55 & 59.06 & 19.79 \\
\hline Microbial Biomass Carbon (mg kg $\left.{ }^{-1}\right)$ & 560.12 & 440.44 & 272.20 \\
\hline $\begin{array}{l}\text { Urease Enzyme } \\
\left(\mu \mathrm{g} \mathrm{NH}{ }_{4}^{+} \text {released } \mathrm{g}^{-1} \text { soil } 0.02 M \text { Urea }^{-1} 2 \mathrm{hr}^{-1}\right)\end{array}$ & 50.40 & 95.20 & 15.24 \\
\hline
\end{tabular}
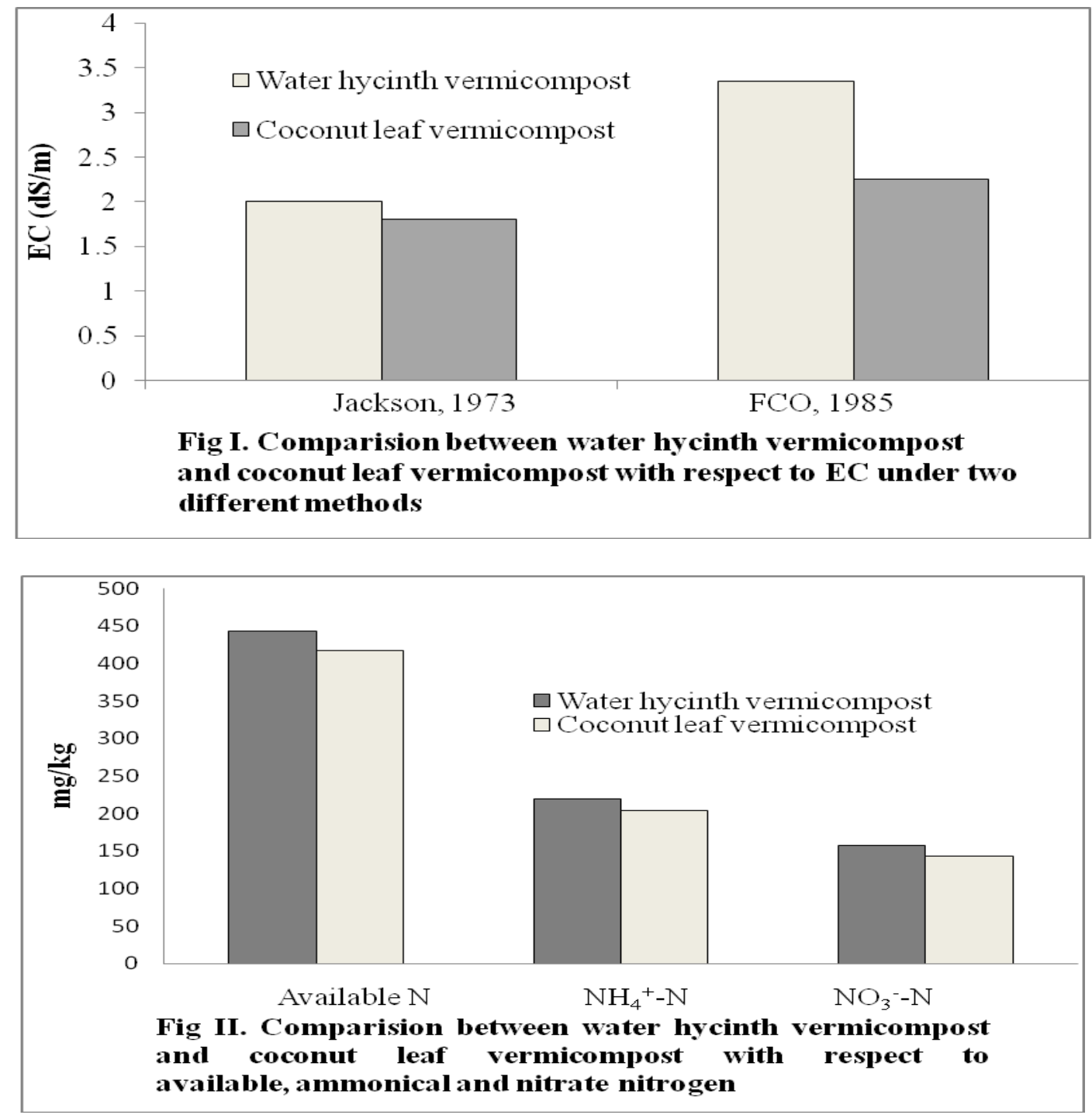

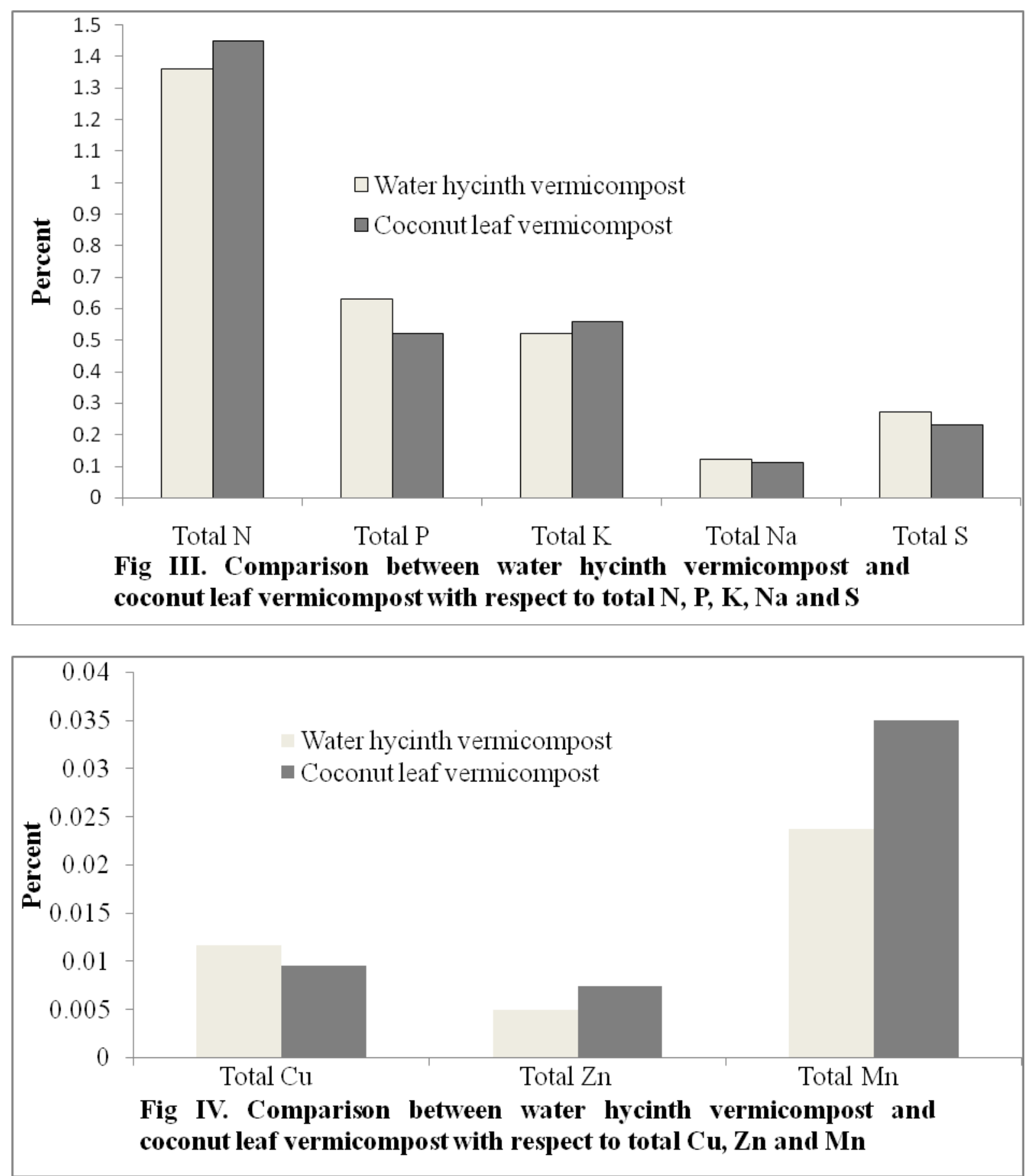

Biological characteristics of vermicomposts

Microbial population like bacteria, actinomycetes, fungi, azotobacter and phosphate solubilising bacteria were counted and presented in Table 2. Total bacteria accounted for fresh vermicompost of water hyacinth and of coconut leaf were $71.70 \times 10^{6}$ and $47.40 \times 10^{6} \mathrm{cfu} \mathrm{g}^{-1}$ dry soil whereas fungi accounted for $23.60 \times 10^{4}$ and $17.40 \times 10^{4} \mathrm{cfu}$ $\mathrm{g}^{-1}$ dry soil, respectively. Population of actinomycetes were $15.40 \times 10^{6}$ and $15.00 \mathrm{x}$ $10^{6} \mathrm{cfu} \mathrm{g}^{-1}$ dry soil. Population of azotobacter and phosphate solubilising bacteria were $12.30 \times 10^{6}$ and $13.60 \times 10^{6} \mathrm{cfu} \mathrm{g}^{-1}$ dry soil in water hyacinth vermicompost as well as 8.00 
x $10^{6}$ and $7.30 \times 10^{6} \mathrm{cfu} \mathrm{g}^{-1}$ dry soil. These results represented that water hyacinth vermicompost are better than coconut vermicompost with respect to microbial population present.

Dehydrogenase activity of water hyacinth vermicompost (87.55 $\mu \mathrm{m}$ TPF h ${ }^{-1} \mathrm{~g}^{-1}$ dry soil) was more than coconut leaf vermicompost $\left(59.06 \mu \mathrm{m} \mathrm{TPF} \mathrm{h}^{-1} \mathrm{~g}^{-1}\right.$ dry soil) whereas in (Table II) cultivated soil it was too low (19.79 $\mu \mathrm{m}$ TPF $\mathrm{h}^{-1} \mathrm{~g}^{-1}$ dry soil). Romaniuk et al., (2011) reported that most of the carbon present on the organic amendments includes partially decomposed material that could be easily used as an energy source by soil microorganisms, resulting in higher respirations rates. Dehydrogenase activity in soils reflects the overall metabolic activity of microorganisms present in particular soils (Dick, 1994). Higher activity in water hyacinth vermicompost reflects that metabolic activity of microorganisms were higher in comparison to coconut leaf vermicompost; the probable reason being the quality of substrate as represented by higher $\mathrm{C}$ content $(23.10 \%)$. Das et al., (2016) reported that vermicompost prepared from water hyacinth waste was recorded in higher respiration rate than other vermicompost that might be due to higher mineralization rate and lowest $\mathrm{C} / \mathrm{N}$ ratio than other vermicompost. The same reason can be cited for higher microbial biomass carbon. Microbial biomass carbon (MBC) content was $560.12 \mathrm{mg} \mathrm{kg}^{-1}$ in water hyacinth vermicompost and $440.44 \mathrm{mg} \mathrm{kg}^{-1}$ in coconut leaf vermicompost while $272.20 \mathrm{mg} \mathrm{kg}^{-1}$ was in cultivated soil. Microbial biomass carbon is considered as the active fraction of carbon (1$5 \%$ of total carbon). Higher microbial population as well as higher carbon content of the water hyacinth vermicompost are responsible for higher MBC. Microbes utilises carbon from the organic substrate and locked them up in their protoplasm which is generally released upon cell death. MBC data reveals that vermicompost of water hyacinth was far better in quality than the vermicompost of coconut leaf. Activity of urease enzyme i.e. production capacity of ammonia was more pronounced in coconut leaf vermicompost $\left(95.20 \mu \mathrm{g} \mathrm{NH}{ }^{+}\right.$released $\mathrm{g}^{-1}$ soil $0.02 M$ urea $\left.^{-1} 2 \mathrm{hr}^{-1}\right)$ than water hyacinth vermicompost $\left(50.40 \mu \mathrm{gg} \quad \mathrm{NH}_{4}{ }^{+}\right.$ released $\mathrm{g}^{-1}$ soil $0.02 M$ urea $\left.^{-1} 2 \mathrm{hr}^{-1}\right)$. This could be of immense importance in managing nitrogen and have impact on their release over the time. Das et al., (2016) also reported similar that urease activity in vermicompost varied depending on the organic wastes used.

From the results of this experiment, it may be inferred that vermicomposts produced separately from different biomass substrate are different in quality with respect to nutrient contents. Microbiological characteristics also differ with changes of substrate for vermicomposting. Vermicompost produced from water hyacinth is better in quality than the vermicompost of coconut leaf with respect to its physicochemical and microbiological characteristics.

\section{References}

Allen, R.W., 1960. Relative susecpebility of various species of earthworms to the larvae of Capillaria annulata. Proc. Helminthol. Soc. Washington. 17, 5864.

Bhat, M.I. and Prabakaran, S., 2013. Vermistabilization of Polyalthia longifolia and Enterolobium saman leaf biomass with cow dung by an epigeic earthworm Eiseniafoetida. International Journal of Environmental Biology. 3,115-117.

Black, C.A., 1965. Methods of Soil Analysis, Parts 1 and 2, American Society of Agronomy.1nc. Publisher, Madicen, Wisconsin, USA. 1-1378.

Chauhan, A., Kumar, S., Singh, A.P., Gupta, 
M., 2010. Vermicomposting of vegetable wastes with cow dung using three earthworm species Eiseniafoetida, Eudriluseugeniae and Perionyx excavates. Nature and Science. 8, 3343.

Chesnin, L. and Yien, C.H., 1951. Turbidimetric determination of available sulphates. Soil Science Society of America Proceedings. 15, 149-151.

Das, D., Bhattacharyya, P., Ghosh, B.C., Banik, P., 2016. Bioconversion and biodynamics of Eiseniafoetida in different organic wastes through microbially enriched vermiconversion technologies, Ecological Engineering. 86, 154-161.

Dick, R.P., 1994. Soil Enzyme Activity as an Indicator of Soil Quality. In: Doran JW et al., editors. Defining soil quality for a sustainable environment., Madison, WI. P 107-124.

Ding J., Wang R., Fu W. and Zhang G., 2001. Water hyacinth in China: Its distribution, problems and control status. In: Biological and integrated control of water hyacinth, Eichhornia crassipes (M.H. Julien, Ed.). Second Meeting of the Global Working Group for the Biological and Integrated Control of Water Hyacinth, Eichhornia crassipes, Beijing, China, pp. 29-32.

Fertilizer Control Order (1985). Biofertilizers and organic fertilizers in Fertilizer (control) order, 1985. Published by National Centre of Organic Farming, Dept. of Agriculture and Corporation, Ministry of Agriculture, Govt. of India.

Irshad, M., Eneji, A.E., Hussain, Z. and Ashraf, M., 2013. Chemical characterization of fresh and composted livestock manures. Journal of Soil Science and Plant Nutrition, 13(1), 115121.

Jackson, M.L., 1973. Soil Chemical Analysis, Pretice Hall of India Pvt. Ltd., New
Delhi.

Jenkinson, D. S. and Powlson, D.S., 1976. The effects of biological treatment on metabolism in soil. V. A. method for measuring soil biomass. Soil Biol. Biochem. 8, 209-213.

Kenny, D. R. and Bremner, J. M., 1962. Chemical Index of Soil Nitrogen Availability. Nature, London, 211, 892893.

Klein, D.A., Loh, T.C. and Goulding, R.L., 1971. A rapid procedure to evaluate dehydrogenase activity in soil of low organic matter. Soil Biology and Biochemistry.3, 385-387.

Lal, R., 2005. World crop residual production and implications of its use as biofuel. Environment International. 31,575-584.

Lindsay, W.L. and Norvell, W.A., 1978. Development of DTPA soil test for zinc, iron, manganese and copper. Soil Science Society of American Journal.42, 421-428.

Malik, A., 2007. Environmental challenge vis a vis opportunity: the case of water hyacinth. Environ. Int. 33, 122-38.

Olsen, S.R., Cole, C.V., Watanabe, F.S. and Dean, L.A., 1954. Estimation of available phosphorus in soils by extraction with sodium bicarbonate. U. S. Department of Agriculture Circular. 939.

Page, A.L., Miller, R.H. and Keeney, D.R. (eds), 1982. Methods of Soil Analysis: Part 2, Chemical and Microbiological Properties. Agronomy Series No 9, American Society of Agronomy, Madison, WI.

Piper, C. S., 1966. Chemical analysis saline soil. Soil and Plants Analysis. Hans Publication, Bombay, India.

Romaniuk, R., Giuffré, L. and Romero, R., 2011. A Soil Quality Index to Evaluate the Vermicompost Amendments Effects on Soil Properties. Journal of Environmental Protection, 2, 502-510. 
Subbiah, B.V. and Asija, G.L., 1956. A rapid procedure for determination of available nitrogen in soils. Current Science.25, 259-260.

Suthar, S., 2007. Composting potential of Perionyx sansibaricus (Perrier) in different waste material. Bioresource Technology. 98, 1231-1237.

Tabatabai, M. A. and Bremner, J. M., 1972, Assay of urease activity in soils, Soil Biol. Biochem. Vol. 4, pp. 479-487.

Tabatabai, M.A., 1982. Sulphur. In: Page A.L., Freney J.R., Miller R.H. (eds.): Methods of Soil Analysis. Part II. Chemical and Microbiological Properties. ASA-CSSA-SSSA, Madison. 501-538.
Vance, E.D., Brookes, P.C. and Jenkinson, D.S., 1987. An extraction method for measuring Soil microbial biomass C. Soil Biol. Biochem. 19, 703-707.

Walkley, A. and Black, I.A., 1934. An examination of Degtjareff method for determining soil organic matter and a proposed modification of the chromic acid titration method. Soil Sci. 37, 2937.

Williams, C.H. and Steinbergs, A., 1959. Soil sulphur fractions as chemical indices of available sulphur in some Australian soils. Australian Journal of Agricultural Research, 10, 340-352.

\section{How to cite this article:}

Ajeet Kumar, Sankar Ch. Paul, Amarjeet Kumar and Mukta Rani. 2018. Comparative Assessment of Physicochemical and Biological Quality Characters of Vermicompost from Different Biomass Substrates. Int.J.Curr.Microbiol.App.Sci. 7(01): 89-97. doi: https://doi.org/10.20546/ijcmas.2018.701.011 